these catheters can therefore easily occlude the neonatal descending aorta, the internal diameter of which is 5 to $6 \mathrm{~mm}$ (Scammon, 1959).

This technique could be applied in other anatomic cases in which angiograms are difficult to obtain; it is particularly suitable for the neonate.

\section{References}

Denham, B. (1978). Aortography in infantile coarctation. British Medical Journal, 1, 1282-1283.
Gyepes, M. T., and Vincent, W. R. (1974). Cardiac Catheterisation and Angiography in Severe Neonatal Heart Disease. Thomas: Springfield.

Scammon, R. E. (1959). Circumferential growth of the aorta. In National Academy of Sciences Handbook of Circulation, p. 20. Edited by D. S. Dittmer and R. Grebe. Saunders: Philadelphia.

Correspondence to Dr B. Denham, Cardiac Department, Our Lady's Hospital for Sick Children, Crumlin, Dublin 12, Eiré.

\title{
Frequency and weight of normal stools in infancy
}

\author{
J. N. LEMOH AND O. G. BROOKE \\ Department of Child Health, St George's Hospital, London
}

SUMMARY These data give a guide to the range of stool weights and their frequency at different ages in infancy. The constancy of stool water content is emphasised.

Burkitt (1976) complained that there are no data on stool weights in normal infants. We have therefore undertaken to provide data on the variation in frequency, weight, and water content of the stools for a group of normal babies and young children fed on cows' milk formulae and mixed diets. The much looser stools of breast-fed infants prevented their inclusion in the study, because it was not possible to prevent spillage.

\section{Materials and methods}

Infants. 55 healthy infants aged between 3 days and 2 years were studied, after obtaining parental cooperation. 33 of the infants were in hospital during the study; 16 of these were aged 3-6 days (normal neonates) and the remaining 17 were in hospital for social reasons. At least 3 days were allowed for these infants to become accustomed to the hospital before collections began. The remaining 22 babies were studied in their homes. The neonates and infants under 4 months were fed ad libitum on proprietary milk formulae, and older infants were on a mixed diet of cereals and formula milk or unmodified cows' milk. Infants who were unwell or who had gastrointestinal symptoms were excluded.

Stool collections. Stools were collected in rayon napkin liners for 3-9 days, median 3.5. A series of in vitro experiments was carried out to determine whether stools collected in this way absorbed water from wet napkins or released water intodry napkins:

\section{Effect of wet napkins}

12 random stool samples weighing, with their liners, between 8.6 and $46 \cdot 1 \mathrm{~g}$ were incubated for 2 hours in disposable napkins which had been soaked in normal saline, whose osmolality approximates that of urine. The stools and liners were then reweighed. Mean weight of stools and liners before incubation was $21 \cdot 2 \mathrm{~g}$, SD $11 \cdot 0$, and after incubation $21.0 \mathrm{~g}$, SD 10.0. Mean change in stool and liner weight was $-0.6 \%$, which was not significant.

\section{Effect of dry napkins}

12 further random stool samples in liners were incubated for 2 hours in dry disposable napkins. Mean weight of stools and liners before incubation was $18 \cdot 5 \mathrm{~g}$, SD $8 \cdot 2$, and after incubation $18 \cdot 1 \mathrm{~g}$, SD $8 \cdot 1$. Mean change in stool and liner weight was $-2 \cdot 7 \%$, again not significant. These findings were confirmed by detecting no significant increase in postdefecation napkin weight when stools were collected in napkin liners in infants wearing urine collection bags.

All stool collections were therefore made by this method, which proved reliable provided that the liners were properly fitted, and enabled stools to be collected at home over reasonable periods of time. At each napkin change, stool adhering to the buttocks was wiped off with the edge of the liner, and the stool and liner were then sealed in plastic bags, labelled with date and time, and frozen. Wet stool weights were subsequently measured in the laboratory, and the stools were freeze dried to determine water content.

\section{Results}

The results are shown in the Table, which divides the children arbitrarily into four age ranges. A total of 
Table Data on stool frequency, weight, and water content in normal infants at different ages

\begin{tabular}{|c|c|c|c|c|}
\hline & Ist week & 8-28 days & $\begin{array}{l}1-12 \\
\text { months }\end{array}$ & $\begin{array}{l}\text { 13-24 } \\
\text { months }\end{array}$ \\
\hline No. of infants & 16 & 11 & 11 & 17 \\
\hline No. of stools & 278 & 139 & 88 & 136 \\
\hline \\
\hline \multicolumn{5}{|l|}{ Mean interval } \\
\hline $\begin{array}{l}\text { (hours) } \pm 1 \text { SD } \\
\text { Range (hours) }\end{array}$ & $\begin{array}{l}5 \cdot 2 \pm 1 \cdot 9 \\
0 \cdot 5-22\end{array}$ & $\begin{array}{l}9 \cdot 9 \pm 6 \cdot 5 \\
0 \cdot 7-38 \cdot 5\end{array}$ & $\begin{array}{c}13 \cdot 2 \pm 9 \cdot 2 \\
0 \cdot 5-53\end{array}$ & $\begin{array}{l}14 \cdot 9 \pm 8 \cdot 3 \\
2-120\end{array}$ \\
\hline \multicolumn{5}{|l|}{ No. of stools } \\
\hline $\begin{array}{l}\text { per } 24 \mathrm{~h} \pm 1 \mathrm{SD} \\
\text { Range }\end{array}$ & $\begin{array}{l}4 \pm 1 \cdot 8 \\
1-12\end{array}$ & $\begin{array}{l}2 \cdot 2 \pm 1 \cdot 6 \\
0-6\end{array}$ & $\begin{array}{l}1 \cdot 8 \pm 1 \cdot 2 \\
0-5\end{array}$ & $\begin{array}{l}1 \cdot 7 \pm 0 \cdot 6 \\
0-3\end{array}$ \\
\hline \multicolumn{5}{|c|}{ Weight of individual } \\
\hline Mean & $4 \cdot 3$ & $11 \cdot 0$ & 17 & 35 \\
\hline Range & $0 \cdot 5-48$ & $0 \cdot 3-40$ & $2-98$ & 4-180 \\
\hline \multicolumn{5}{|l|}{ Stool water content } \\
\hline $\begin{array}{l}\text { Mean } \\
\text { Range }\end{array}$ & $\begin{array}{l}72 \cdot 8 \pm 5 \cdot 0 \\
65-84\end{array}$ & $\begin{array}{l}73 \cdot 3 \pm 2 \cdot 7 \\
72-77\end{array}$ & $\begin{array}{l}75 \cdot 0 \pm 3 \cdot 0 \\
72-80\end{array}$ & $\begin{array}{l}73 \cdot 8 \pm 3 \cdot 2 \\
66-81\end{array}$ \\
\hline
\end{tabular}

641 stools were examined. As expected there was a wide range of individual variation in stool weight and frequency, but the general trend of an increase in weight and decrease in frequency with age is apparent. However, even in the second year it was common for the children to pass more than one stool a day, although some children went for 2-3 days without defecation in the absence of clinical 'constipation'. Stool water content hardly varied from the first week to the second year and had a remarkably small SD. There was no correlation between stool frequency and stool weight.

\section{Comment}

The only published information on defecation patterns in infancy is by Colón and Jacob (1977) who investigated the subject by using questionnaires. The parents in their study reported that more than half the children passed one stool daily after 18 months. These findings seem on the optimistic side for British children who on average continue to pass more than one stool per 24 hours until 2 years of age. Colón and Jacob (1977) obtained no data on stool weights.

The surprising finding in this investigation was the constancy of stool water content, apparently finely controlled to maintain an even stool consistency throughout the age range. Since stool water is easy to measure and remains so constant in health, it could be an unnecessarily neglected marker of gastrointestinal disease and deserves future study.

We intend that the range of variation in stool weight and frequency given in the Table should give some long-needed guidance for child health workers as to what constitutes 'normality'. The study also confirms the effectiveness of napkin liners.

We acknowledge the invaluable help of Mrs $\mathbf{M}$. Lewis in the data collection.

\section{References}

Burkitt, D. P. (1976). Letter: Stool weights in western children. Lancet, 2, 633.

Colón, A. R., and Jacob, L. J. (1977). Defecation patterns in American infants and children. Clinical Pediatrics, 16, 999-1000.

Correspondence to Dr O. G. Brooke, Department of Child Health, St George's Hospital, Cranmer Terrace, London SW17 ORE.

\title{
Infantile hypertrophic pyloric stenosis-unusual familial incidence
}

\author{
V. R. FINSEN
}

Department of Surgery, Paediatric Section, Regionsykehuset, Trondheim, Norway

SUMMARY A man, who had been treated for infantile hypertrophic pyloric stenosis (PS), was found to have 3 sons with the same condition. A genealogical table of his family showed that both his parents had relatives with PS. So far as it was known, none of his wife's relatives had the condition. It is suggested that the man's parents carried genes predisposing to PS and transmitted these to him in such quantity that he and all his children acquired the condition.

The aetiology of infantile hypertrophic pyloric stenosis (PS) is largely unknown. It has long been recognised that there is an increased preponderance of the condition in the relatives of patients. This familial predisposition is shown very clearly in the family to be described.

A patient $\left(\mathrm{IV}_{4}\right.$ in the Figure) had an operation at this hospital some years ago for PS. On further investigation it was found that both his brothers $\left(\mathrm{IV}_{3}\right.$ and $\left.\mathrm{IV}_{5}\right)$ and his father $\left(\mathrm{III}_{6}\right)$ had been treated for the same condition. The main features of their case histories are summarised in the Table.

A genealogical table stretching over four generations was assembled for this family (Figure). The patient's mother had no known relatives with PS, but both his paternal grandfather and grandmother $\left(\mathrm{II}_{3}\right.$ 